\title{
Innovating (a Lot) With a Little: High-Tech Innovation in Southeast Europe
}

DOI: 10.7595/management.fon.2021.0033

\begin{abstract}
:
Motivation: According to the European Innovation Scoreboard (EIS, 2020), Southeast-European countries are either modest or moderate innovators because they consistently innovate below the EU average. Given that innovation is a key driver of economic growth (Hasan \& Tucci, 2010), this implies that Southeast Europe has been economically falling back while simultaneously politically integrating with the EU. However, the EIS categorizes countries according to the inconclusive arithmetic mean of indicators for firm-level innovation (bottom-up) and indicators for inputs and enablers of innovation at the national level (top-down). Besides, it does not separately assess innovation performance of high-technology industries although these are crucial for international competitiveness (Schwab, 2019). Consequently, this paper answers the following research question: What is innovation performance of high and medium-high technology industries in Southeast Europe in comparison to the EU average? Idea: In contrast to the EIS which merges top-down with bottom-up innovation indicators, the core idea of this paper has been to analyse only bottom-up data on comparative innovation performance of high and medium-high technology industries in Southeast Europe. Method and data: The paper methodologically draws on guidelines for collecting, reporting, and using data on innovation by Oslo Manual (OECD \& Eurostat, 2018), and uses secondary data from 2010-2016 Community Innovation Surveys of enterprises to compile an own set of 140 data points. Innovation activity within an industry is defined as the ratio of innovative enterprises to the total population of enterprises while innovation performance is the ratio of innovation activity in the respective country to innovation activity of this industry in the whole EU. Tools: All data points have been arranged country-wise as unbalanced contingency panels and plotted to draw conclusions on innovation performance of high and medium-high technology industries in Southeast Europe. Findings: Although all top-down innovation inputs and enablers at the national level are far below the EU average throughout Southeast Europe, several industries in the region reach or surpass the average EU innovation performance: the pharmaceutical industry in Croatia, all medium-high technology industries in Turkey, manufacture of machinery in North Macedonia and Serbia, as well as manufacture of motor vehicles in all countries except for Romania. Contributions and limitations: This is the first known paper to benchmark innovation performance of high and medium-high technology industries throughout Southeast Europe. In addition, the paper reveals the shortcomings of the whole-country method employed by the EIS since it clearly points out that innovation performance of national industries should be assessed instead. Limitations of the paper are the exclusive focus on innovation as a process and partly restricted data availability.
\end{abstract}

Keywords: Innovation; performance; high technology; medium-high technology; Southeast Europe.

JEL Classification: $032,038,039,052$.

\section{Introduction}

The Lisbon Strategy set the goal for the European Union (EU) "to become the most competitive and dynamic knowledge-based economy in the world" within a decade (EP, 2000). As a tool to track the implementation of the Lisbon Strategy, the European Innovation Scoreboard (EIS) has been introduced and first published already in 2001. While the Lisbon Strategy has meanwhile failed (Copeland, 2012), the EIS continues to exist and provide annual comparative analyses of innovation performance of the EU members, several non-EU European countries, and global competitors of the EU like China, Russia, and the USA. In its most recent edition (EIS, 2020), the EIS covers 27 EU members, 9 non-EU European countries and 10 global competitors. 
Innovation is a multidimensional phenomenon which signifies either the process or its outcome, and which may occur at several levels, from a single firm to the whole world (OECD \& Eurostat, 2018). Common innovation metrics typically employ either bottom-up or top-down approaches. Bottom-up metrics collect data about innovation at the firm level and aggregate them to the national or industry level. Top-down metrics capture elements of national innovation systems (OECD, 1997) such as institutional strength, R\&D spending, and infrastructural conditions, all of which serve as enabler of, or inputs to, the innovation process at the firm level. The EIS merges both approaches by aggregating 19 top-down and 8 bottom-up indicators into a single composite indicator, the summary innovation index, which is calculated as the unweighted average of all 27 indicators.

According to this index, Southeast-European countries have consistently failed to reach the EU average. In 2019 for example, Bulgaria, North Macedonia, and Romania achieved less than $50 \%$ of the EU average and are categorised as modest innovators. Croatia, Serbia, and Turkey performed better, reaching 50 to $95 \%$ of the EU average, so they are categorized as moderate innovators (EIS, 2020). Since innovation is a key driver of economic growth (Hasan \& Tucci, 2010), the summary innovation index implies that Southeast Europe has been economically falling back while simultaneously politically integrating with the EU - Bulgaria and Romania accessioned the EU in 2007, Croatia in 2013, and the remaining countries in the region have been in the accession process. However, given the method used to calculate the summary innovation index, the EIS categorizes countries according to the inconclusive arithmetic mean of firm-level innovation and national-level inputs and enablers thereof. Besides, while the EIS does consider the share of medium and high technology products in national exports, it remains mute about innovation performance of high and mediumhigh technology industries although these are particularly important for international competitiveness of countries (Schwab, 2019).

Consequently, this paper aims at a bottom-up exploration of innovation performance of high and medium-high technology industries in Southeast Europe in comparison to the EU average. The next section reviews extant literature on this topic and observes a contradiction between theoretical predictions and empirical data, lack of relevant and conclusive metrics, and absence of comparative assessments in academic sources. The subsequent section defines the method and data used in this paper to benchmark innovation performance of high and medium-high technology industries in the region. Thereafter, the results are presented country-wise to reveal that innovation activity in many industries in the region lays in fact at or above the EU average. These findings clearly point out the shortcomings of the whole-country method employed by the EIS, and are finally discussed along with other implications, limitations, and future research opportunities.

\section{Literature Review}

In addition to the summary innovation index, which is composed of 19 top-down and 8 bottom-up indicators, the EIS aggregates groups of 2 or 3 indicators into sub-indices. Top-down indicators are aggregated into 7 sub-indices for factors at the national level which serve as enabler of, or inputs to, the innovation process at the firm level. These sub-indices capture human resources (composed of indicators for new doctorate graduates, population aged 25-34 with tertiary education, and lifelong learning), attractive research systems (international scientific co-publications, top 10\% most cited publications, foreign doctorate students), innovation-friendly environment (broadband penetration, opportunity-driven entrepreneurship), finance and support (public R\&D expenditures and venture capital expenditures), firm investments (R\&D expenditures in the business sector, non-R\&D innovation expenditures, ICT training), linkages (SMEs collaborating with others, public-private co-publications, private co-funding of public R\&D expenditures) and intellectual assets (patent, trademark and design applications).

Human resources, paired with appropriate human resource management systems, induce proactive behaviour, and enable firms to engage in innovation (Curado, 2018; Ko \& Ma, 2019; Whee et al., 2019). Innovation effects of attractive research systems, higher education and hiring of tertiary degree employees are positive and significant (Hervas-Oliver et al., 2011; Pegkas et al., 2019; Szucs, 2018). Internet penetration has a significant (although diminishing and lagged) innovation-promotion effect (Xiong et al., 2021), whereas opportunity-driven entrepreneurship (as opposed to necessity-driven, job-substitution entrepreneurship) is concomitantly innovation-driven (Bosma et al., 2020). Empirical evidence equally proves positive and significant innovation effects of business, public and higher education R\&D expenditures (Barra \& Zotti, 2018; Pegkas et al., 2019), research subsidies (Szucs, 2018), as well as of non-R\&D innovation expenditures such as licensing, trial production, tooling-up, employee training, marketing research and investment in fixed assets (Brouwer \& Kleinknecht, 1997; Hervas-Oliver et al., 2011). As for venture capital, Dessí \& Yin (2012) report substantial impact on innovation at the industry level, although evidence for individual firms is lacking. 
Linkages and related recombination of knowledge that exists beyond firms' organizational boundaries play a fundamental role for the innovation process (Savino et al., 2017). Finally, intellectual assets contribute to both innovation and economic growth (Bismuth \& Tojo, 2008). In short, extant literature unambiguously acknowledges that all inputs and enablers considered by the EIS are significant for innovation. Given that these inputs and enablers are far below the EU average throughout Southeast Europe (Table 1), extant literature implicitly predicts lower innovation performance in the region as compared to the EU, medium-high and high-tech industries included.

Table 1: Innovation inputs and enablers in Southeast Europe, \% of the EU average

\begin{tabular}{|l|c|c|c|c|c|c|}
\hline Innovation input/enabler & Bulgaria & Croatia & $\begin{array}{c}\text { N. } \\
\text { Macedonia }\end{array}$ & Romania & Serbia & Turkey \\
\hline Human resources & $52 \%$ & $57 \%$ & $38 \%$ & $12 \%$ & $61 \%$ & $41 \%$ \\
\hline Attractive research systems & $26 \%$ & $44 \%$ & $81 \%$ & $29 \%$ & $39 \%$ & $36 \%$ \\
\hline $\begin{array}{l}\text { Innovation-friendly } \\
\text { environment }\end{array}$ & $43 \%$ & $41 \%$ & $51 \%$ & $65 \%$ & $69 \%$ & $69 \%$ \\
\hline Finance and support & $12 \%$ & $39 \%$ & $13 \%$ & $42 \%$ & $40 \%$ & $45 \%$ \\
\hline Firm investments (in R\&D) & $41 \%$ & $91 \%$ & $62 \%$ & $8 \%$ & $86 \%$ & $89 \%$ \\
\hline Linkages & $35 \%$ & $66 \%$ & $17 \%$ & $39 \%$ & $68 \%$ & $47 \%$ \\
\hline Intellectual assets & $83 \%$ & $35 \%$ & $14 \%$ & $26 \%$ & $9 \%$ & $22 \%$ \\
\hline
\end{tabular}

Source: EIS, 2020

However, the EIS innovators sub-index partly contradicts this theoretical prediction. This bottom-up subindex aggregates shares of enterprises with product or process innovations, marketing or organisational innovations, and enterprises innovating in-house. According to the innovators sub-index, Turkey was innovation leader in 2019 (above 125\% of the EU average), Croatia and Serbia strong innovators (between $95 \%$ and $125 \%$ ) while Bulgaria, North Macedonia and Romania were still modest innovators. Unfortunately, this sub-index remains inconclusive since it considers only small and medium sized enterprises and does not differentiate among industries.

Ranking of innovation at the national level is a subject of several measurement frameworks, notably Global Innovation Index, Bloomberg Innovation Index, and International Innovation Index, all of which consider some or all Southeast-European countries. The 2020 Global Innovation Index (Cornel University et al., 2020) ranks innovation performance of 131 countries based on 7 pillars: institutions, human capital and research, infrastructure, market sophistication, business sophistication, knowledge and technology outputs, and creative outputs. Rather than against a benchmark, it assesses innovation performance against expectations for the respective level of development. In 2019, innovation performance of Bulgaria, North Macedonia, and Serbia was above expectations, of Croatia and Romania in line with expectations, and of Turkey below expectations. This is an interesting but - in our context - too coarse-grained a piece of information.

The annual Bloomberg Innovation Index (Bloomberg, 2020) ranks 60 most innovative countries in the world. It is based on R\&D intensity, manufacturing value-added, productivity, high-tech density, tertiary efficiency, researcher concentration, and patent activity. For this paper potentially interesting sub-index for high-tech density is calculated as the percentage of high-tech companies in the population of all publicly listed domestic companies. This unfortunately does not provide any information about innovation performance of firms in high-tech industries, whether publicly or privately owned.

The International Innovation Index (Andrew et al., 2009) ranks 110 countries according to 2 sub-indices, innovation input and innovation performance. The sub-index for innovation performance is composed of 3 scores: for R\&D results, public impact of innovation, and business performance. The latter includes only high-tech exports, labour productivity, and market capitalisation of listed companies, all of which are of limited help when it comes to the benchmarking of innovation performance at the industry level.

A keywords-based search in ProQuest for academic literature on comparative innovation performance in Southeast Europe identifies only 8 articles and conference papers published in English since 2000, of which 6 have been excluded from further considerations since they cover individual countries only. Remaining 2 items do not pertain to high-tech industries (Table 2). 
Table 2: Academic literature on innovation performance in Southeast Europe

\begin{tabular}{|c|c|c|}
\hline Item & Scope & Method and main findings \\
\hline $\begin{array}{l}\text { Kaynak et } \\
\text { al., } 2017\end{array}$ & $\begin{array}{l}\text { Ranking of overall } \\
\text { innovation performance of } \\
\text { EU candidates Iceland, } \\
\text { North Macedonia, Serbia, } \\
\text { and Turkey }\end{array}$ & $\begin{array}{l}\text { - Technique for Order Performance by Similarity to } \\
\text { Ideal Solution (TOPSIS) } \\
\text { - Iceland always ranked first; ranks of other EU } \\
\text { candidates depend on data source used. } \\
\text { - If EIS data are used, the ranking is Iceland, Serbia, } \\
\text { Turkey, North Macedonia, which is consistent with } \\
\text { the EIS ranking. }\end{array}$ \\
\hline $\begin{array}{l}\text { Toth et al., } \\
2018\end{array}$ & $\begin{array}{l}\text { Drivers of innovation per- } \\
\text { formance of food industry } \\
\text { in Bulgaria, Croatia, } \\
\text { Cyprus, Estonia, Germany, } \\
\text { Hungary, Lithuania, } \\
\text { Norway, Portugal, } \\
\text { Romania, Slovakia, and } \\
\text { Spain }\end{array}$ & $\begin{array}{l}\text { - Regression analysis } \\
\text { - Innovation performance is explained by } \\
\text { networking scope, networking intensity, and } \\
\text { market openness and obstacles. } \\
\text { - Food industries in Bulgaria and Romania are least } \\
\text { innovative (modest innovators); the performance } \\
\text { in Croatia is moderate. }\end{array}$ \\
\hline
\end{tabular}

In sum, innovation literature implicitly predicts lower innovation performance in Southeast Europe as compared to the EU average; however, conclusive metrics with this regard are lacking. Common rankings follow the top-down approach and focus on the capacity of national innovation systems. They provide useful information about the environment within which Southeast-European high-tech industries innovate, yet they say hardly anything about how well they perform in this regard. The EIS goes beyond this and provides a bottom-up sub-index on innovation activity, yet this index considers only small and medium sized enterprises and does not differentiate among industries. Academic publications on comparative innovation performance in Southeast Europe are hardly existent; besides, they provide only fragmented snapshots regarding points of time, industries and countries included.

\section{Method and Data}

Given that this paper aims at exploring innovation performance of high and medium-high technology industries in Southeast Europe in comparison to the EU average, we first define industries and countries to consider. For industries, we apply the Eurostat classification of technological intensity (Eurostat, n.d.) based on NACE Rev. 2 (Eurostat, 2008) at 2-digit level (Table 3).

Table 3: High and medium-high technology industries

\begin{tabular}{|l|l|l|}
\hline Technology level & NACE & Industry \\
\hline $\begin{array}{l}\text { Medium-high- } \\
\text { technology }\end{array}$ & C20 & Manufacture of chemicals and chemical products \\
\hline High technology & C21 & $\begin{array}{l}\text { Manufacture of basic pharmaceutical products and } \\
\text { preparations }\end{array}$ \\
\hline High technology & C26 & Manufacture of computer, electronic and optical products \\
\hline $\begin{array}{l}\text { Medium-high- } \\
\text { technology }\end{array}$ & C27 & Manufacture of electrical equipment \\
\hline $\begin{array}{l}\text { Medium-high- } \\
\text { technology }\end{array}$ & C28 & $\begin{array}{l}\text { Manufacture of machinery and equipment not elsewhere } \\
\text { classified }\end{array}$ \\
\hline $\begin{array}{l}\text { Medium-high- } \\
\text { technology }\end{array}$ & C29 & Manufacture of motor vehicles, trailers, and semi-trailers \\
\hline $\begin{array}{l}\text { Medium-high- } \\
\text { technology }\end{array}$ & C30 & Manufacture of other transport equipment \\
\hline
\end{tabular}

Source: Eurostat, n.d. 
Since conflicting views exist as to which countries Southeast Europe encompasses, we commence from the view implied by the Lisbon Strategy, in which Greece is considered a part of Southern and Slovenia part of Central Europe. However, we include only the countries covered by the EIS, i.e. Bulgaria, Croatia, North Macedonia, Romania, Serbia, and Turkey (although in fact only East Thrace is a geographical part of Europe). All industry-level data from Montenegro are confidential, so Montenegro has been excluded from further considerations.

Innovative enterprises are defined in the sense of the EIS, as enterprises that have introduced an outcome of innovation or have any kind of innovation activities, including abandoned, suspended, or ongoing ones. Innovation activity within an industry is defined as the ratio of innovative enterprises to the total population of enterprises. Finally, innovation performance is the ratio of innovation activity of an industry in the respective country to innovation activity of this industry in the whole EU.

For example, in NACE industry C27 (manufacture of electrical equipment), there were 10.529 enterprises in the EU in 2016, of which 6.957 were innovative (66\%). In the same year, 58\% of C27 enterprises in Bulgaria were innovative, so innovation performance of C27 in Bulgaria for 2016 is $0,58 / 0,66=0,8787$ or roughly $88 \%$ of the EU average.

Innovation performance is determined by drawing on publicly available data from the Community Innovation Survey database (CIS, n.d.). The CIS is an extensive survey of enterprises regarding their innovation activities and outcomes; it is carried out every even calendar year by all EU members and several non-EU states. It provides statistics broken down by country, industry, type of innovators, and enterprise sizes. We extract relevant CIS data since 2010 (Table 4), because most Southeast-European countries started carrying out CIS surveys that year. Processing of survey microdata takes more than two years (EIS, 2020), so CIS data for 2018 were not available at the time of this writing. Whereas the shares of innovative enterprises for each industry in Southeast-European countries have been obtained directly from the CIS, the shares for the whole EU have been self-compiled.

Table 4: Extracted CIS data

\begin{tabular}{|l|l|l|l|l|}
\hline & CIS 2010 & CIS 2012 & CIS 2014 & CIS 2016 \\
\hline Table & inn_cis7_type & inn_cis8_type & inn_cis9_type & inn_cis10_type \\
\hline Size class & All enterprises & All enterprises & All enterprises & All enterprises \\
\hline Fields & INNO, TOTAL & INNO, TOTAL & INNO, TOTAL & INN, TOTAL \\
\hline Description & $\begin{array}{l}\text { - INNO, INN: Share of enterprises that have either introduced an innovation or have } \\
\text { any kind of innovation activity including abandoned, suspended, or ongoing } \\
\text { innovation activities. } \\
\text { - TOTAL: Total number of enterprises }\end{array}$ \\
\hline
\end{tabular}

Eventually, an asymmetric data set of 140 data points has been created. Each data point has 4 attributes: country, industry, year, and innovation performance. In this set, 28 data points are missing: North Macedonia did not participate in CIS 2010 and 2012 (14 data points); Turkey did not participate in 2010 at all (7 data points) and in 2012 only with some industries (4 data points); and CIS data from Romania for NACE industry C21 (pharmaceuticals) are confidential since 2012 (3 data points). All available data points have been arranged country-wise as unbalanced contingency panels, plotted, and analysed.

\section{Findings}

\subsection{Bulgaria}

Overall, the trend in Bulgaria is clear and encouraging; innovation activity in high and medium-high tech industries has been increasing in comparison to the EU average since 2010. In 2016, the performance of each industry was at or above $75 \%$ of the EU average. Medium-high tech industries C29 (manufacture of motor vehicles) and C30 (manufacture of other transport equipment) perform particularly well and have reached the EU level. Manufacture of computers and electronics (C26), a high-tech industry, seems also to be catching up, although slower (from 62\% in 2010 to $77 \%$ in 2016). Chemicals (C20) and pharmaceuticals (C21; high-tech) are of some concern as they persist at roughly $75 \%$ of the EU average. 


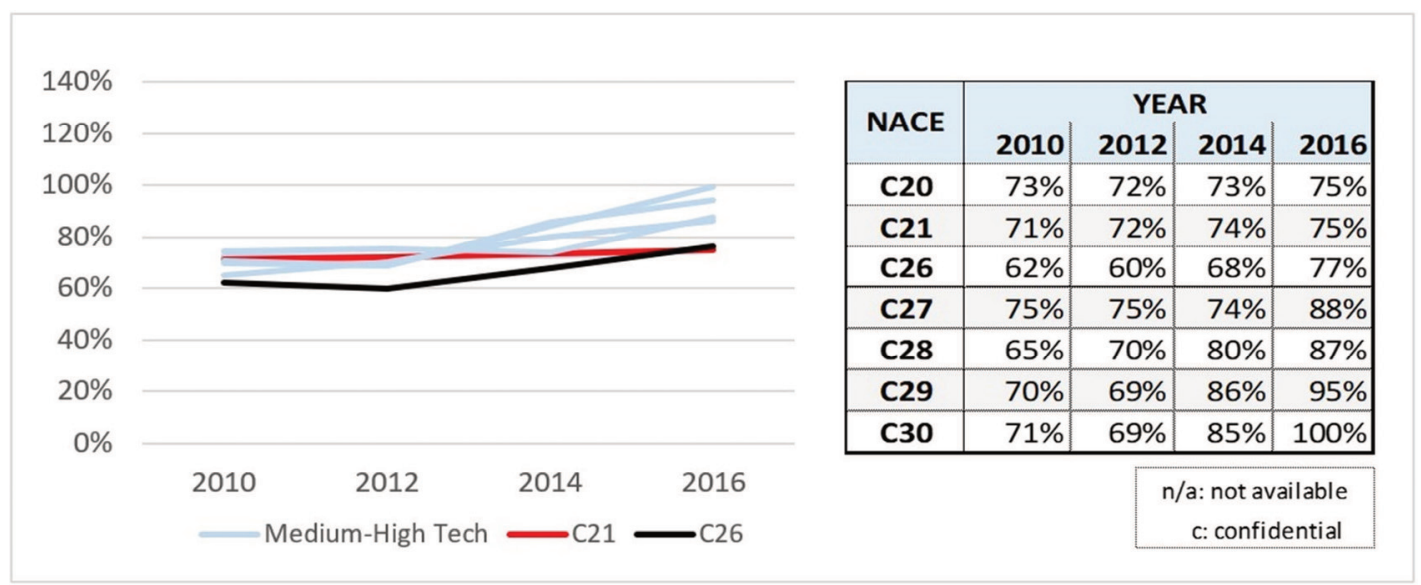

Figure 1: Innovation performance in Bulgaria

\subsection{Croatia}

In Croatia, the pharmaceutical industry (C21) has taken a straight upward trend since 2010 to surpass the EU average and reach $125 \%$ thereof in 2016. All other industries have shown a zigzag pattern to some degree, manufacture of motor vehicles (C29) even extremely so (from $128 \%$ down to $51 \%$ and then back to $108 \%$ ). In 2016, manufacturing of electrical equipment (C27) was also more innovative than the EU average $(108 \%)$. In contrast, manufacturing of other transport equipment (C30) is staying far behind, at around $50 \%$ of the EU average. C26 (computers and electronics) had a severe setback from 2010 to 2012 but has been slowly recovering since.

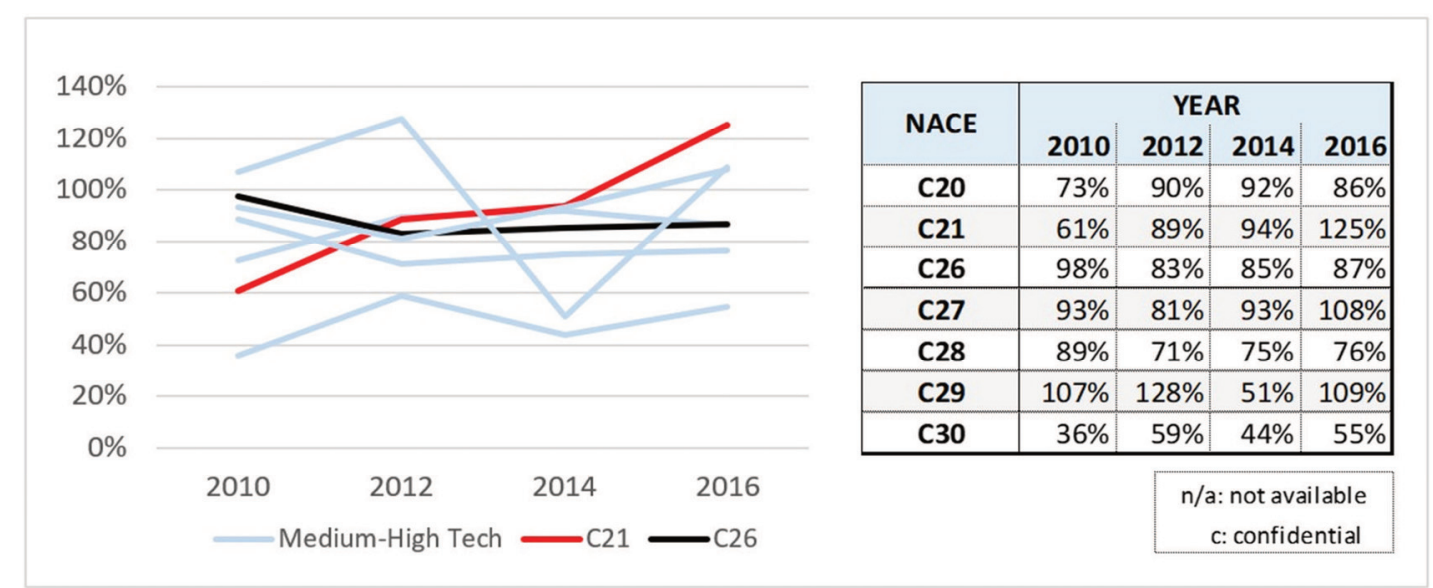

Figure 2: Innovation performance in Croatia

\subsection{North Macedonia}

North Macedonia participated only in two CIS so far, therefore the changes in performance from 2014 to 2016 should be taken with a considerable grain of proverbial salt. Besides, these changes are mirrored: some industries (C20, C28 and C30) improved in comparison to the EU as strongly as the others (C21, C26, C27 and C29) lost ground. In any case, in 2016, manufacture of machinery and equipment (C28) and manufacture of motor vehicles (C29) were innovating above, and pharmaceuticals (C21) roughly at the EU level. Despite a big jump from $6 \%$ of the EU average in 2014 to $45 \%$ in 2016 , the chemical industry (C20) is still far behind. Of particular concern seems to be the performance drop of C26 (computers and electronics) from $95 \%$ in 2014 to $52 \%$ in 2016. 


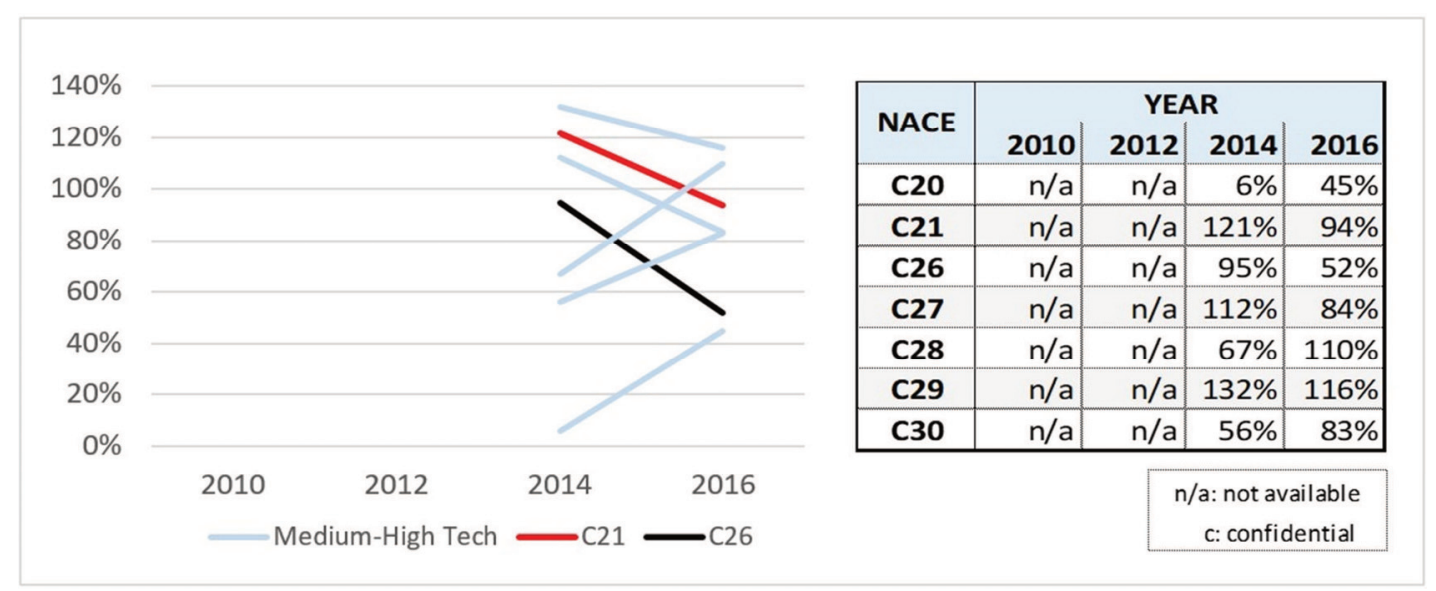

Figure 3: Innovation performance in North Macedonia

\subsection{Romania}

The trend in Romania is as clear as alarming: innovation activity in all high and medium-high tech industries has been gradually decreasing since 2010 to fall - in most cases by far - below a third of the EU average in 2016. C26 (computers and electronics) is by far the worst performing high-tech industry in Southeast Europe, reaching only $15 \%$ of the EU average in 2016. Note that data on C21 (pharmaceuticals) are confidential since 2012 and hence not available. In that year, however, C21 was the best performing Romanian industry regarding innovation activity ( $74 \%$ of EU average).

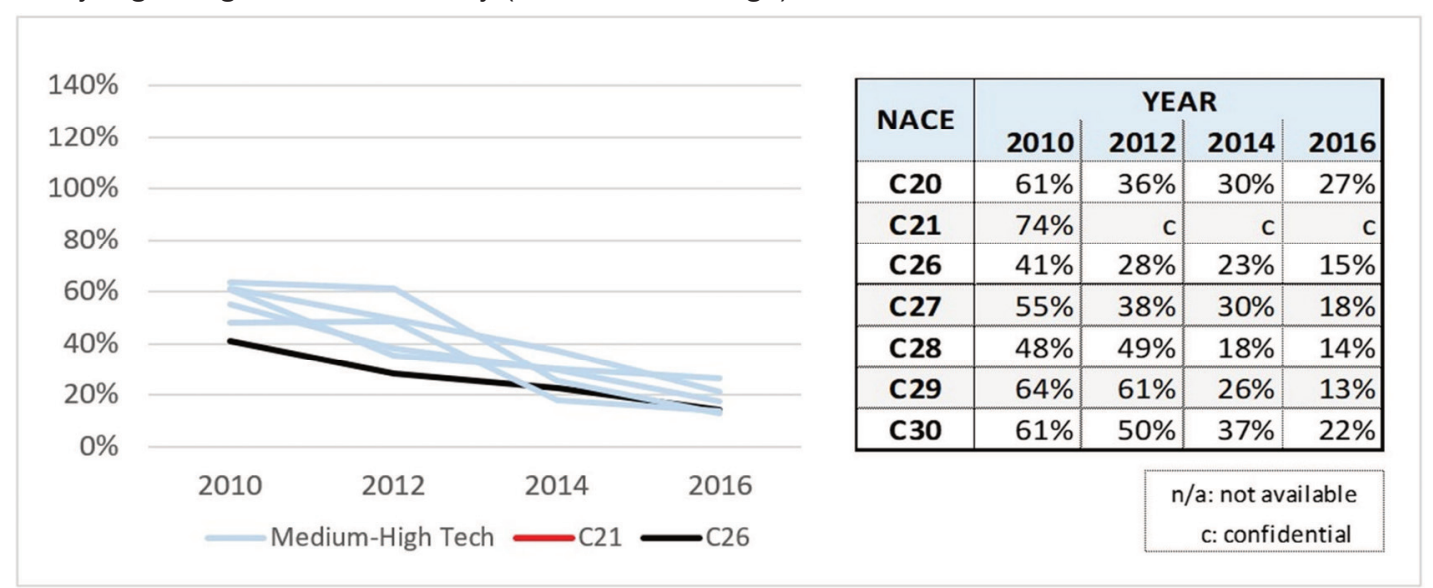

Figure 4: Innovation performance in Romania

\subsection{Serbia}

The changes of innovation performance in Serbian high and medium-high tech industries are, on the one hand, mirrored as in the case of North Macedonia, while, on the other, they show a zigzag pattern as in Croatia. Pharmaceuticals (C21) and manufacturing of motor vehicles (C29) have been oscillating around, but basically keeping up with, the EU average. Steep deterioration of innovation activity within the computers and electronics industry (C26) is alarming. In fact, this is the second worst performing high-tech industry in Southeast Europe. 


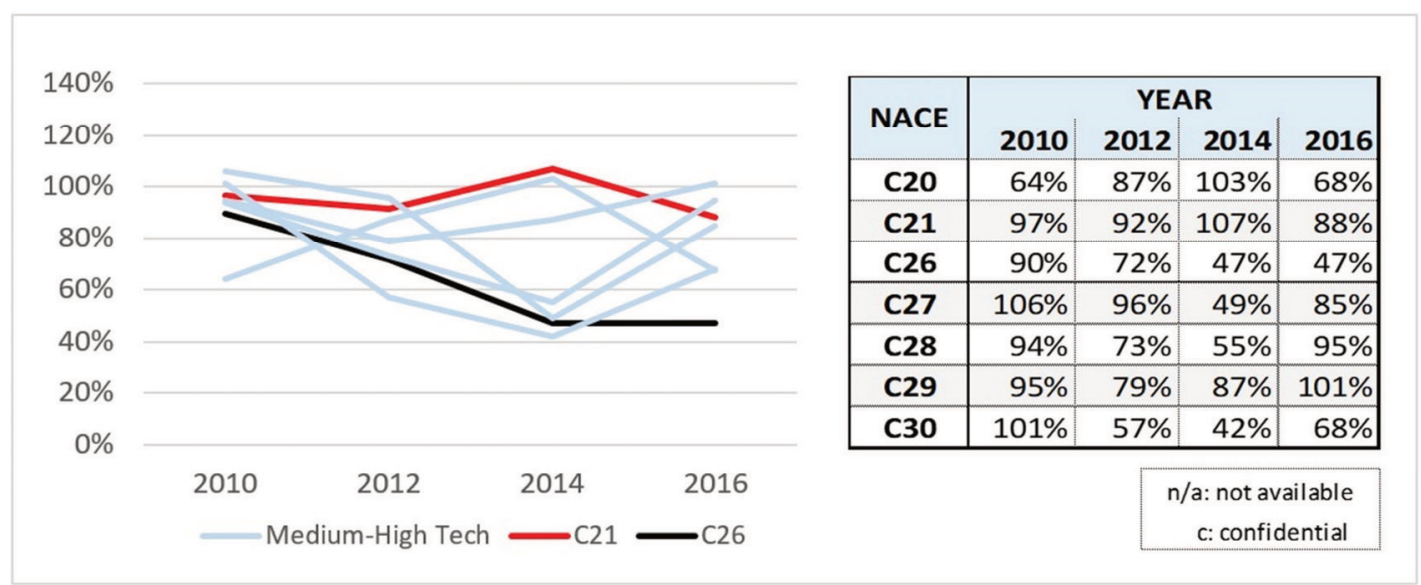

Figure 5: Innovation performance in Serbia

\subsection{Turkey}

In 2016, Turkish high-tech industries C21 (pharmaceuticals) and C26 (computers and electronics) were innovating only 7 respectively 4 percentage points below the EU, while innovation activity in all medium-high tech industries was between 5 and 23 percentage points above the EU level. The status was hence clearly favourable in 2016, yet the trends are neither stable nor well recognisable given that Turkey did not participate in $2010 \mathrm{CIS}$ at all and in 2012 only with 3 industries (C20, C21, and C26).

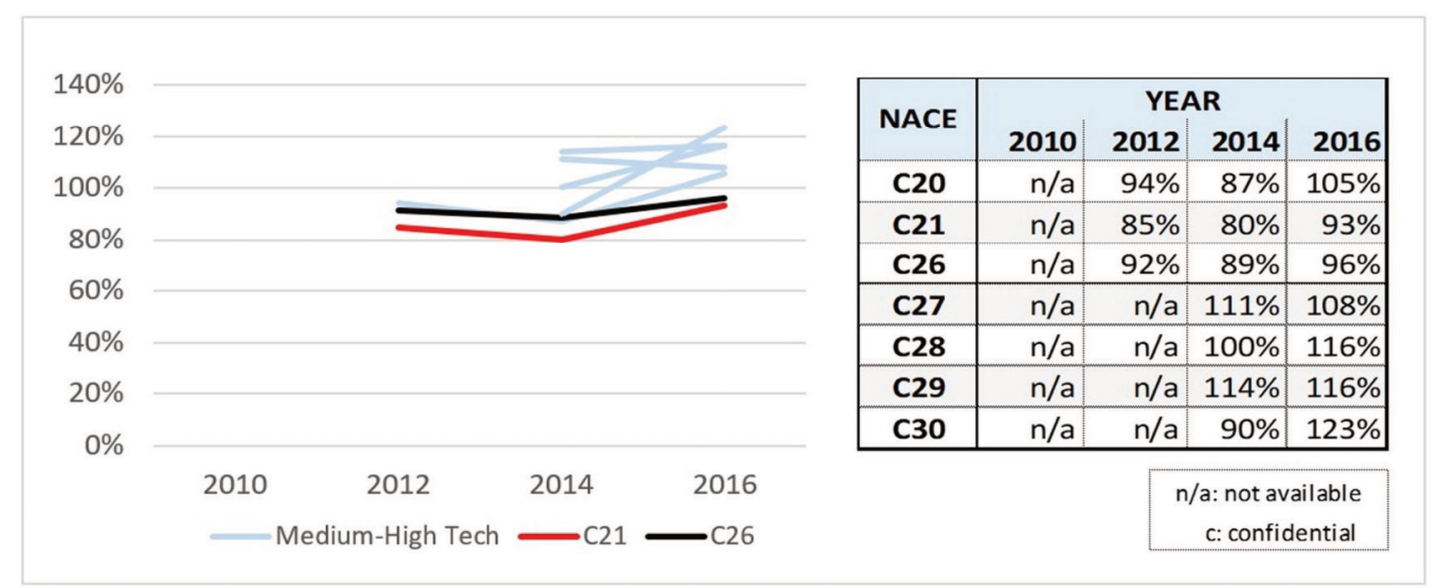

Figure 6: Innovation performance in Turkey

\section{Discussion and Conclusion}

This paper presents a differentiated picture of innovation performance in Southeast-European high and medium-high tech industries, which may be of particular interest to executives and policymakers. The pharmaceutical industry (C21) in Croatia is the only high-tech innovation leader in the region; the strength of Southeast Europe are rather its medium-high tech industries. All medium-high tech industries (C20, C27-C30) are strong innovators in Turkey; manufacture of machinery (C28) is also a strong innovator in North Macedonia and Serbia, and manufacture of motor vehicles (C29) in the whole region except for Romania. Concomitantly, there are several problem children that require attention, for example all high and medium-high tech industries in Romania, computers and electronics (C26) in Serbia, and chemicals (C20) in North Macedonia.

Consequently, the paper makes two major contributions. To the best of our knowledge, this is the first academic paper to benchmark innovation performance of high and medium-high tech industries throughout Southeast Europe. These industries are of particular interest given their importance for international competitiveness of the countries in the region 
(Schwab, 2019) and therefore for their economic integration with the EU. In addition, the paper reveals the shortcomings of the method employed by the EIS to assess innovation performance. The EIS assigns whole countries to categories modest/moderate/strong innovators and innovation leaders based on the summary innovation index which is calculated as the arithmetic mean of bottom-up (i.e. firm-level) and top-down (country-level) indicators. Consequently, the summary innovation index does not (and simply cannot) differentiate between the environment within which Southeast-European firms innovate (top-down indicators) and their performance in this regard (bottom-up indicators). The EIS innovators subindex fails to overcome this shortcoming because it considers only innovation activity of small and medium-sized enterprises and does not differentiate among industries. In contrast, our findings clearly point out that the innovativeness of industries, rather than of whole countries, should be assessed. This is plausible given that national industries lay at intersection of national (OECD, 1997) and sectorial innovation systems (Malerba, 2002).

For example, the EIS categorizes Turkey as a moderate innovator since the country's summary innovation index reaches roughly $62 \%$ of the EU average. The country scores this low despite the innovators sub-index of $151 \%$ of the EU average, which means that small and medium-sized enterprises in all Turkish industries are in fact innovation leaders at aggregated level. This discrepancy results from the fact that inputs and enablers of innovation in Turkey are mostly far below the EU average (EIS, 2020; see also Table 1 above). Put bluntly, the EIS overall assessment "punishes" Turkey because its firms innovate under adverse conditions - although at least small and medium-sized firms nevertheless overperform the EU. Our findings provide a different and differentiated picture here: pharmaceuticals industry (C21) in Turkey is a moderate innovator (93\% of the average EU innovation performance), while all other high and medium-high tech industries are strong innovators (between $96 \%$ and $123 \%$ of the EU average). In fact, manufacturing of other transport equipment (C30) is even close to an innovation leader (123,3\%).

Whereas the major contribution of this paper is clearly practical, it nevertheless raises a few theoretical questions, which in turn translate into promising research opportunities. Several patterns of innovation performance presented in Figures 1-6 deserve being explained, for example zigzag trends in Croatia and Serbia, bisection of innovation performance in North Macedonia, or the collapse of innovation activity in Romania. Dealing with the specifics of each industry and/or country goes beyond the scope of this paper but should be in the focus of subsequent research so as to provide both theoretical insights and a fundament for targeted policy intervention.

Most importantly, it is puzzling that innovation activity in many industries in the region lays above the EU average although all innovation inputs and enablers at the national level are below it (Table 1). There are at least four approaches that - individually or jointly - may provide a potential explanation here. First, it is possible that these industries outperform the EU average not despite but because of comparatively low inputs and enablers, as resource scarcity may trigger innovation activity in adverse contexts (Cunha et al., 2014). In line with this, exactly the prevalence of necessity-driven, job-substitution entrepreneurship (Bosma et al., 2020) may equally encourage innovation activity.

Second, national policies may play either a promoting (Bloom et al., 2019; Schot \& Steinmueller, 2018), moderating (Garcia-Perez-de-Lema et al., 2017) or detrimental role (Barra \& Zotti, 2018) regarding innovation activity of firms.

Third, the EIS framework may be subject to endogenous flaws. Out of 82 commonly used innovation indicators (Dziallas \& Blind, 2019), the EIS includes only 27. Besides, the EIS uses unweighted averages of single indicators to calculate composite indices, which is possibly not appropriate given that the impact of inputs and enablers on innovation may be curvilinear (Shi et al., 2020) or moderated (Rajalo \& Vadi, 2017; Szucs 2018).

Finally, innovation is a multidimensional phenomenon (OECD \& Eurostat, 2018); at the firm level, its two dimensions are innovation as a process or activity, and innovation as an outcome (Crossan \& Apaydin, 2010). In this paper, only the former dimension is observed. However, as Savino et al. (2017) note, innovation activity is a necessary yet not sufficient prerequisite for innovation outcome to occur. Consequently, Southeast-European high and medium-high tech industries that innovate more than the EU average may - like proverbial hamsters - fail to transfer innovation activity into marketable new products and services, and ultimately economic gains.

In addition to exclusive focus on innovation as a process, a limitation of this paper is data availability. Our data panels are insightful but partly incomplete and short; besides, most recent data are from 2016. It is simply that Southeast-European countries started executing CIS surveys relatively recently, that CIS data are made available with a lag of over 2 years, and that some figures (C21 in Romania, all industry data from Montenegro) are deemed confidential. Longitudinal and/or twodimensional explorations of innovation performance in the region are hence warranted and yet to come.

\section{Acknowledgment}

An early version with some parts of this paper has been presented at the 6th International Scientific Conference on Contemporary Issues in Economics, Business and Management (EBM 2020) in Kragujevac, Serbia. 


\section{REFERENCES}

[1] Andrew, J. P., DeRocco, E. S., \& Taylor, A. (2009). The Innovation Imperative in Manufacturing: How the United States Can Restore Its Edge. Boston, MA: Boston Consulting Group.

[2] Barra, C., \& Zotti, R. (2018). The contribution of university, private and public sector resources to Italian regional innovation system (in)efficiency. Journal of Technology Transfer, 43(2), 432-457. DOI:10.1007/s10961-016-9539-7

[3] Bismuth, A., \& Tojo, Y. (2008). Creating value from intellectual assets. Journal of Intellectual Capital, 9(2), 228-245. DOI:10.1108/14691930810870319

[4] Bloom, N., Van Reenen, J., \& Williams, H. (2019). A Toolkit of Policies to Promote Innovation. Journal of Economic Perspectives, 33(3), 163-184. DOI:10.1257/jep.33.3.163

[5] Bloomberg (2020). Bloomberg Innovation Index: Germany Breaks Korea's Six-Year Streak as Most Innovative Nation. Retrieved from https://www.bloomberg.com/news/articles/2020-01-18/germany-breakskorea-s-six-year-streak-as-most-innovative-nation

[6] Bosma, N., Hill, S., lonescu-Somers, A., Kelley, D., Levie, J., \& Tarnawa, A. (2020). Global Entrepreneurship Monitor: Global Report 2019/2020. Retrieved from https://www.gemconsortium.org/report/gem-2019-2020-global-report

[7] Brouwer, E., \& Kleinknecht, A. (1997). Measuring the unmeasurable: A country's non-R\&D expenditure on product and service innovation. Research Policy, 25(8), 1235-1242.

DOI:10.1016/S0048-7333(96)00902-X

[8] CIS (n.d.). Science, Technology, and Innovation Database. Accessed at https://ec.europa.eu/eurostat/web/science-technology-innovation/data/database

[9] Copeland, P. (2012). Conclusion: The Lisbon Strategy - Evaluating Success and Understanding Failure. In P. Copeland \& D. Papadimitriou (Eds.), The EU's Lisbon Strategy: Evaluating Success, Understanding Failure. London: Palgrave Macmillan. DOI:10.1057/9781137272164

[10] Cornel University, INSEAD, \& WIPO (2020). Global Innovation Index 2020: Who Will Finance Innovation? Ithaca, Fontainebleau, and Geneva. Retrieved from https://www.wipo.int/edocs/pubdocs/en/wipo_pub_gii_2020.pdf

[11] Crossan, M. M., \& Apaydin, M. (2010). A Multi-Dimensional Framework of Organizational Innovation: A Systematic Review of the Literature. Journal of Management Studies, 47(6), 1154-1191. DOI:10.1111/j.1467-6486.2009.00880.x

[12] Cunha, M. P. e, Rego, A., Oliveira, P., Rosado, P., \& Habib, N. (2014). Product Innovation in ResourcePoor Environments: Three Research Streams. Journal of Product Innovation Management, 31(2), 202210. DOI:10.1111/jpim.12090

[13] Curado, C. (2018). Human resource management contribution to innovation in small and medium-sized enterprises: A mixed methods approach. Creativity and Innovation Management, 27(1), 79-90. DOI:10.1111/caim.12251

[14] Dessi, R., \& Yin, N. (2012). The Impact of Venture Capital on Innovation. In D. Cumming (Ed.), The Oxford Handbook of Venture Capital. Oxford University Press. DOI:10.1093/oxfordhb/9780195391596.013.0023

[15] Dziallas, M., \& Blind, K. (2019). Innovation indicators throughout the innovation process: An extensive literature analysis. Technovation, 80-81, 3-29.DOI:10.1016/j.technovation.2018.05.005

[16] EIS (2020). European Innovation Scoreboard 2020. Luxembourg: Publications Office of the European Union. Retrieved from https://ec.europa.eu/growth/industry/policy/innovation/scoreboards_en

[17] EP (2000). Lisbon European Council 23-24 March 2000: Presidency Conclusions. Brussels: European Parliament. Retrieved from http://aei.pitt.edu/43340/

[18] Eurostat (2008). NACE Rev. 2: Statistical Classification of Economic Activities in the European Community. Luxembourg: Publications of the European Communities. Retrieved from https://ec.europa.eu/eurostat/web/products-manuals-and-guidelines/-/KS-RA-07-015

[19] Eurostat (n.d.). Aggregations of Manufacturing Based on NACE Rev. 2. Retrieved from https://ec.europa.eu/eurostat/cache/metadata/Annexes/htec_esms_an3.pdf

[20] Garcia-Perez-de-Lema, D., Madrid-Guijarro, A., \& Martin, D. P. (2017). Influence of university-firm governance on SMEs innovation and performance levels. Technological Forecasting and Social Change, 123, 250-261. DOI:10.1016/j.techfore.2016.04.003

[21] Hasan, I., \& Tucci, C. L. (2010). The Innovation-Economic Growth Nexus: Global Evidence. Research Policy, 39(10), 1264-1276. DOI:10.1016/j.respol.2010.07.005

[22] Hervas-Oliver, J.-L., Albors Garrigos, J., \& Gil-Pechuan, I. (2011). Making sense of innovation by R\&D and non-R\&D innovators in low technology contexts: A forgotten lesson for policymakers. Technovation, 31(9), 427-446. DOI:10.1016/j.technovation.2011.06.006

[23] Kaynak, S., Altuntas, S., \& Dereli, T. (2017). Comparing the innovation performance of EU candidate countries: An entropy-based TOPSIS approach. Ekonomska Istrazivanja, 30(1), 31-54. DOI:10.1080/1331677X.2016.1265895 
[24] Ko, Y. J., \& Ma, L. (2019). Forming a firm innovation strategy through commitment-based human resource management. International Journal of Human Resource Management, 30(12), 1931-1955. DOI:10.1080/09585192.2017.1308415

[25] Malerba, F. (2002). Sectoral Systems of Innovation and Production. Research Policy, 31(2), 247-264. DOI:10.1016/S0048-7333(01)00139-1

[26] OECD (1997). National Innovation Systems. Paris: OECD Publications. Retrieved from https://www.oecd.org/science/inno/2101733.pdf

[27] OECD \& Eurostat (2018). Oslo Manual 2018: Guidelines for Collecting, Reporting and Using Data on Innovation, 4th Edition. OECD Publishing, Paris/Eurostat, Luxembourg.

[28] Pegkas, P., Staikouras, C., \& Tsamadias, C. (2019). Does research and development expenditure impact innovation? Evidence from the European Union countries. Journal of Policy Modeling, 41(5), 10051025. DOI:10.1016/j.jpolmod.2019.07.001

[29] Rajalo, S., \& Vadi, M. (2017). University-industry innovation collaboration: Reconceptualization. Technovation, 62-63, 42-54. DOI:10.1016/j.technovation.2017.04.003

[30] Savino, T., Messeni Petruzzelli, A., \& Albino, V. (2017). Search and Recombination Process to Innovate: A Review of the Empirical Evidence and a Research Agenda. International Journal of Management Reviews, 19(1), 54-75. DOI:10.1111/ijmr.12081

[31] Schot, J., \& Steinmueller, W. E. (2018). Three frames for innovation policy: R\&D, systems of innovation and transformative change. Research Policy, 47(9), 1554-1567. DOI:10.1016/j.respol.2018.08.011

[32] Schwab, K. (Ed.). (2019). The Global Competitiveness Report 2019: How to end a lost decade of productivity growth. Geneva: World Economic Forum. Retrieved from https://www.weforum.org/reports/how-to-end-a-decade-of-lost-productivity-growth

[33] Shi, X., Wu, Y., \& Fu, D. (2020). Does University-Industry collaboration improve innovation efficiency? Evidence from Chinese Firms. Economic Modelling, 86, 39-53. DOI:10.1016/j.econmod.2019.05.004

[34] Szucs, F. (2018). Research subsidies, industry-university cooperation and innovation. Research Policy, 47(7), 1256-1266. DOI:10.1016/j.respol.2018.04.009

[35] Toth, J., Torok, A., \& Balogh, J. M. (2018). Networking Theory of Innovation in Practice: A Pan-European Overview Based on the Community Innovation Survey. 2018 Conference of the International Association of Agricultural Economists, Vancouver, BC. DOI:10.22004/ag.econ.277158

[36] Whee, L. H., Pak Jongwook, Seongsu, K., \& Long-Zhen, L. (2019). Effects of Human Resource Management Systems on Employee Proactivity and Group Innovation. Journal of Management, 45(2), 819846. DOI: $10.1177 / 0149206316680029$

[37] Xiong, F., Zang, L., \& Gao, Y. (2021). Internet penetration as national innovation capacity: Worldwide evidence on the impact of ICTs on innovation development. Information Technology for Development, 117. DOI:10.1080/02681102.2021.1891853

Received: 2021-05-27

Revisions requested: 2021-07-12

Revised: 2021-09-14

Accepted: 2021-10-11

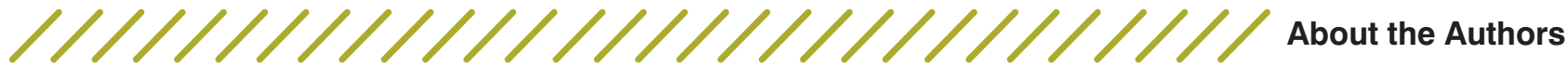

\section{Nebojša Radojević \\ Shenzhen Technology University, School of Business, Shenzhen, China nebojsa.radojevic@hec.ca}

Nebojša Radojević is a full professor of strategic and project management at the Shenzhen Technology University with 20 years of previous professional experience as a manager, project manager and management consultant for large international corporations and higher levels of government. His research focuses on innovation strategy and management, innovation metrics, and links between corporate governance and innovation. Nebojša Radojević holds a PhD in International Business and an MBA from University of Montreal, a master's degree in Computer Science from Dresden University of Technology, and professional credentials in project and programme management.

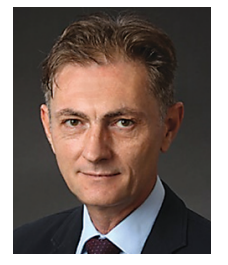

